\title{
EFFECTS OF $\mathrm{AN}^{\mathrm{Al}_{2} \mathrm{O}_{3}}$ NANO-ADDITIVE ON THE PERFORMANCE OF CERAMIC COATINGS PREPARED WITH MICRO-ARC OXIDATION ON A TITANIUM ALLOY
}

\author{
UČINKI $\mathrm{Al}_{2} \mathrm{O}_{3}$ NANODODATKA NA TITANOVO ZLITINO PRI \\ IZVEDBI KERAMIČNIH PREVLEK, PRIPRAVLJENO Z \\ MIKROOBLOČNO OKSIDACIJO
}

\author{
Çağatay Demirbaş, Aysun Ayday \\ Sakarya University, Faculty of Engineering, Department of Metallurgical and Materials Engineering, Sakarya, 54187, Turkey \\ aayday@sakarya.edu.tr \\ Prejem rokopisa - received: 2016-07-15; sprejem za objavo - accepted for publication: 2016-11-08
}

doi: $10.17222 / \mathrm{mit} .2016 .194$

\begin{abstract}
In this research, nano-sized $\mathrm{Al}_{2} \mathrm{O}_{3}$ particles were added to silicate-based coatings and the effect of these particles on the microstructure, composition and properties of the coatings was investigated. The effects of the nano-additive on the structure, phase composition and hardness of the micro-arc oxidation (MAO) coatings were analysed using scanning electron microscopy (SEM), X-ray diffraction and micro-hardness testing. The SEM showed that the coatings with a nano-additive have lower porosities than those without a nano-additive. XRD results showed that the coatings with nano-additives contain more oxide when compared to those without nano-additives. The results showed that the nanoparticle additions improve the hardness of the MAO coatings.

Keywords: micro-arc oxidation (MAO), nano-additive, alumina, Ti6Al4V

$\mathrm{V}$ raziskavi so $\mathrm{Al}_{2} \mathrm{O}_{3}$ nanodelci dodani osnovi s silikatnimi prevlekami. Raziskan je bil učinek teh delcev na mikrostrukturo, sestavo in lastnosti prevlek. Analizirani so bili učinki nanodelcev na strukturo, fazno sestavo in trdoto mikroobločne oksidacije (angl. MAO) pri premazih, in sicer z vrstično elektronsko mikroskopijo (SEM), z rentgensko difrakcijo in $\mathrm{z}$ mikrotrdoto. SEM-analiza je pokazala, da imajo prevleke $\mathrm{z}$ nanododatkom nižjo poroznost od tistih, katerih prevleke ne vsebujejo nanododatkov. Rezultati XRD kažejo, da prevleke $\mathrm{z}$ nanododatki vsebujejo več oksidov $\mathrm{v}$ primerjavi $\mathrm{s}$ tistimi brez nanododatkov. Rezultati še kažejo, da dodatki nanodelcev izboljšajo trdoto MAO-prevlek.

Ključne besede: mikroobločna oksidacija, nanododatki, glinica, Ti6Al4V
\end{abstract}

\section{INTRODUCTION}

Titanium and its alloys are widely used in aerospace, automation, chemical industry and biomedicine because of their high strength, low density and good biocompatibility. However, their surface hardness and corrosion resistance limit their applications. Many studies aim to improve their hardness and corrosion resistance. ${ }^{1-3}$

MAO is a plasma-assisted surface treatment technique used to convert the surfaces of suitable metals to thick and hard ceramic-oxide layers. ${ }^{4,5}$ However, ceramic coatings generally possess a foam-like structure with a high bulk porosity and relatively poor mechanical properties, which restrict them from even wider technical applications. ${ }^{5}$ Researches mainly focused on the effects of the processing parameters, such as current density, voltage and electrolytic solution for improving the mechanical properties; nowadays, nano-additive doping of the electrolyte is also studied to improve the properties of the ceramic coatings. ${ }^{4,6,7}$ In this research, the effect of a nano- $\mathrm{Al}_{2} \mathrm{O}_{3}$ additive to the electrolyte on the Ti6Al4V microstructure, phase composition and microhardness of MAO coatings on a titanium alloy were analysed.

\section{EXPERIMENTAL PART}

The Ti6Al4V substrate material used for the investigation had a chemical composition in mass fractions $(w / \%)$ of $6.3 \mathrm{Al}, 4.2 \mathrm{~V}, 0.15 \mathrm{O}, 0.11 \mathrm{Fe}, 0.03 \mathrm{C}, 0.02 \mathrm{~N}$, $0.001 \mathrm{H}$ and Ti balance. The samples with a size of $\Phi 5 \times$ $70 \mathrm{~mm}$ were ground with 1000-grit silicon-carbide papers, cleaned with alcohol and then dried in hot air. The electrolytes were prepared from solutions of $8.75 \%$ $\mathrm{Na}_{2} \mathrm{SiO}_{3} \mathrm{~g} / \mathrm{L}-1.25 \% \mathrm{NaOH} \mathrm{g} / \mathrm{L}-0.6 \% \mathrm{Na}_{2} \mathrm{~B}_{4} \mathrm{O}_{7} \mathrm{~g} / \mathrm{L}$ (MAO-Ti) and $8.75 \% \mathrm{Na}_{2} \mathrm{SiO}_{3} \mathrm{~g} / \mathrm{L}-1.25 \% \mathrm{NaOH} \mathrm{g} / \mathrm{L}$

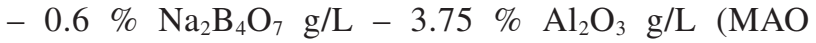
(nano)-Ti) in distilled water (Table 1). During the MAO treatment, the applied voltage, treatment time and cooling system (electrolyte) were fixed at $400 \mathrm{~V}, 15 \mathrm{~min}$ and $30 \pm 5{ }^{\circ} \mathrm{C}$, respectively. The microstructural characteristics of the coating and phase composition were investigated with scanning electron microscopy (SEM, JOEL) and X-ray diffraction (XRD, Shimadzu XRD6000). Table 1 shows the components, $\mathrm{pH}$ and conductivity of the electrolytes of the samples. The hardness values of the uncoated Ti6Al4V and coated samples were measured using a FUTURE TECH-CORP.FM-700 microhardness tester at a load of $100 \mathrm{~g}$ for a loading time 
Ç. DEMIRBAŞ, A. AYDAY: EFFECTS OF AN $\mathrm{Al}_{2} \mathrm{O}_{3}$ NANO-ADDITIVE ON THE PERFORMANCE ...

Table 1: Coated samples and characteristics of their coating electrolytes

\begin{tabular}{|c|c|c|c|c|}
\hline Sample codes & $\begin{array}{c}\text { Electrolyte components } \\
(\mathrm{g} / \mathrm{L})\end{array}$ & $\begin{array}{c}\text { Nano- } \mathrm{Al}_{2} \mathrm{O}_{3} \\
(\mathrm{~g} / \mathrm{L})\end{array}$ & $\begin{array}{c}\text { Electrolyte } \\
\mathrm{pH}\end{array}$ & $\begin{array}{c}\text { Electrolyte } \\
\text { conductivity (ms/cm) }\end{array}$ \\
\hline MAO-Ti & $\begin{array}{c}(8.75 \%) \mathrm{Na}_{2} \mathrm{SiO}_{3} /(1.25 \%) \mathrm{NaOH} / \\
(0.6 \%) \mathrm{Na}_{2} \mathrm{~B}_{4} \mathrm{O}_{7}\end{array}$ & - & 12 & 11.5 \\
\hline $\mathrm{MAO}(\mathrm{Nano})-\mathrm{Ti}$ & $\begin{array}{c}(8.75 \%) \mathrm{Na}_{2} \mathrm{SiO}_{3} /(1.25 \%) \mathrm{NaOH} / \\
(0.6 \%) \mathrm{Na}_{2} \mathrm{~B}_{4} \mathrm{O}_{7}\end{array}$ & $(3.75 \%)$ & 12.3 & 14 \\
\hline
\end{tabular}

of $10 \mathrm{~s}$. The average of three repeated measurements was reported.

\section{RESULTS AND DISCUSSION}

Figure 1 shows the surface morphologies of the coated samples. A highly non-uniform porous layer, with an average pore size ranging from 5-10 $\mu \mathrm{m}$ was observed on the surface of the MAO-Ti coating (Figure 1a to $\mathbf{1 b})$. With an addition of nano- $\mathrm{Al}_{2} \mathrm{O}_{3}$, the coating surface became denser and smoother and the number of pores decreased (Figure 1c to 1d). It can be concluded that the addition of a nanopowder plays an essential role in fabricating ceramic coatings with a lower porosity.
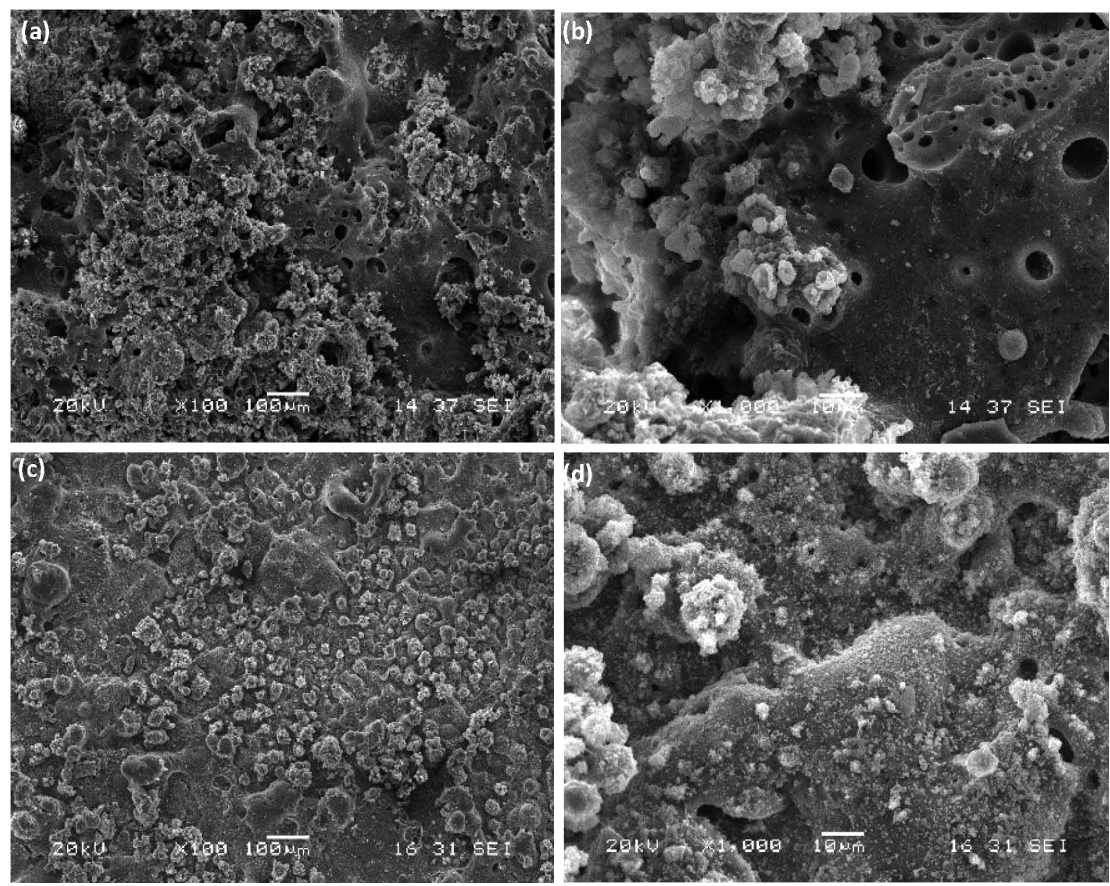

Figure 1: Surface morphologies of the MAO-treated Ti: a) to b) MAO-Ti and an addition of nano- $\left.\mathrm{Al}_{2} \mathrm{O}_{3}, \mathrm{c}\right)$ to d) $\mathrm{MAO}\left(\mathrm{Nano}_{\text {) }} \mathrm{Ti}\right.$
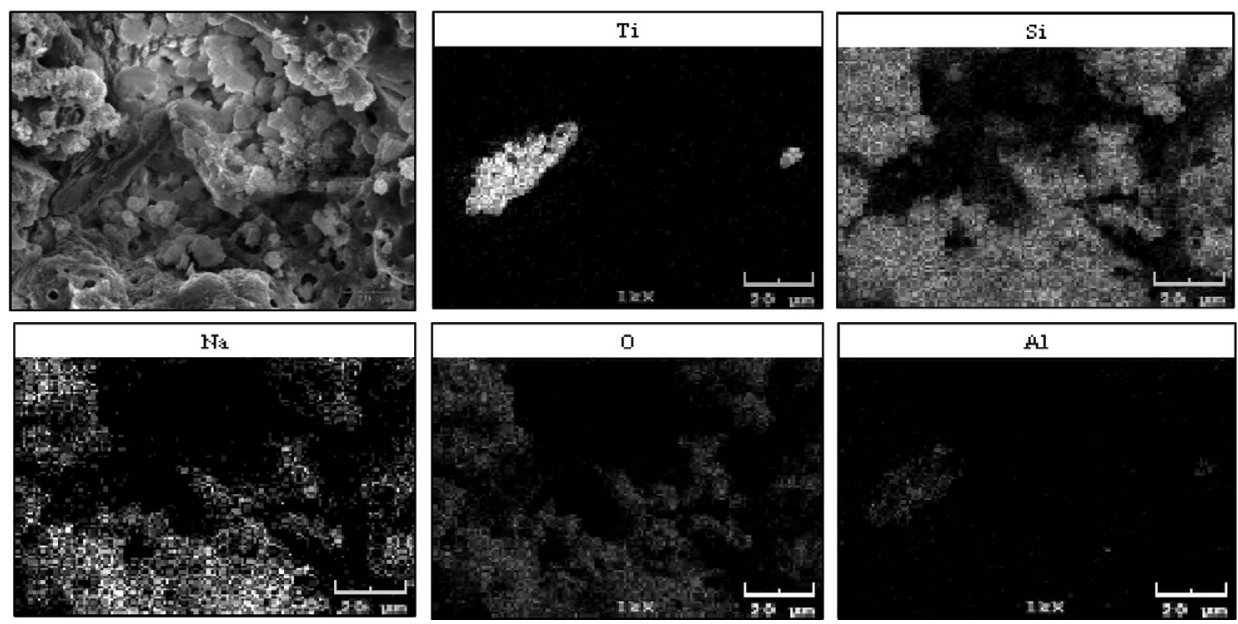

Figure 2: EDS map analysis of MAO-Ti (without a nano-additive) 
Ç. DEMIRBAŞ, A. AYDAY: EFFECTS OF AN Al ${ }_{2} \mathrm{O}_{3}$ NANO-ADDITIVE ON THE PERFORMANCE ...
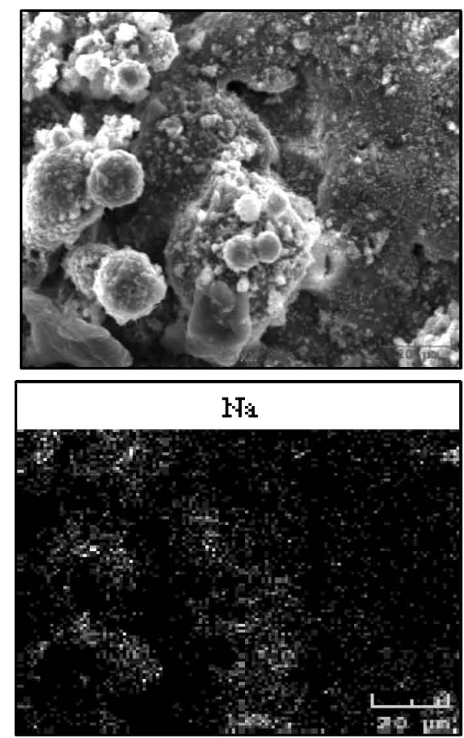
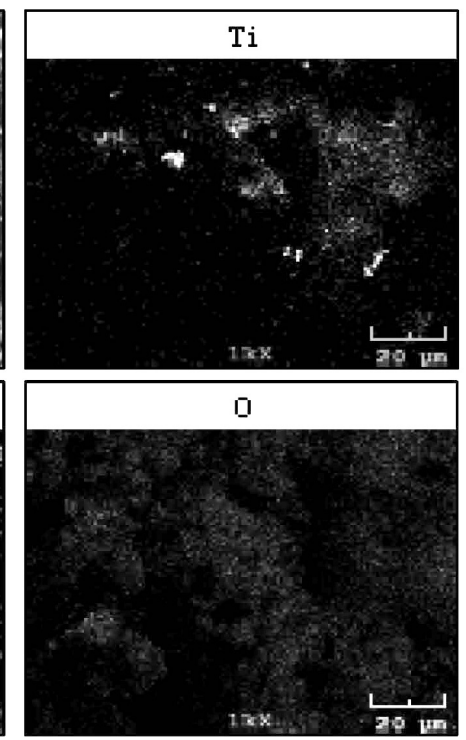
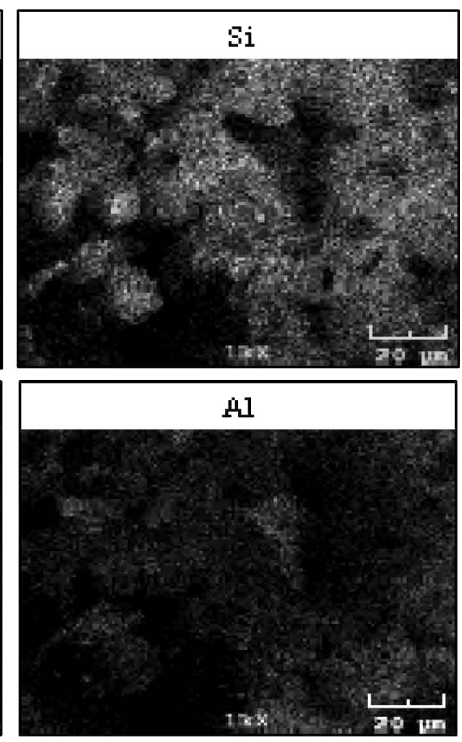

Figure 3: EDS map analysis of MAO (nano)-Ti (with a nano-additive)

Some of the $\mathrm{Al}_{2} \mathrm{O}_{3}$ nanoparticles were drawn into the discharge channel during the micro-arc discharge because of the force of the conductivity of the electrolytes. The addition of $\mathrm{Al}_{2} \mathrm{O}_{3}$ nanoparticles to the electrolyte improved its conductivity and the sparks generated in the anode reaction intensified. This led to a significant increase in the number of micro-arcs per unit time, resulting in an increase in the number of micro-arc pores and a reduction in the size of the pores formed on the sample surface. Smaller pores increase the compactness of the coating microstructure. ${ }^{8}$

The EDS map analysis of the MAO coatings without a nano-additive is shown in Figure 2. The main elements were $\mathrm{Ti}$ and $\mathrm{O}$, which were found in all the coatings and came from the substrate. $\mathrm{Na}$ and $\mathrm{Si}$ were detected on nearly all the surfaces and these elements came from the

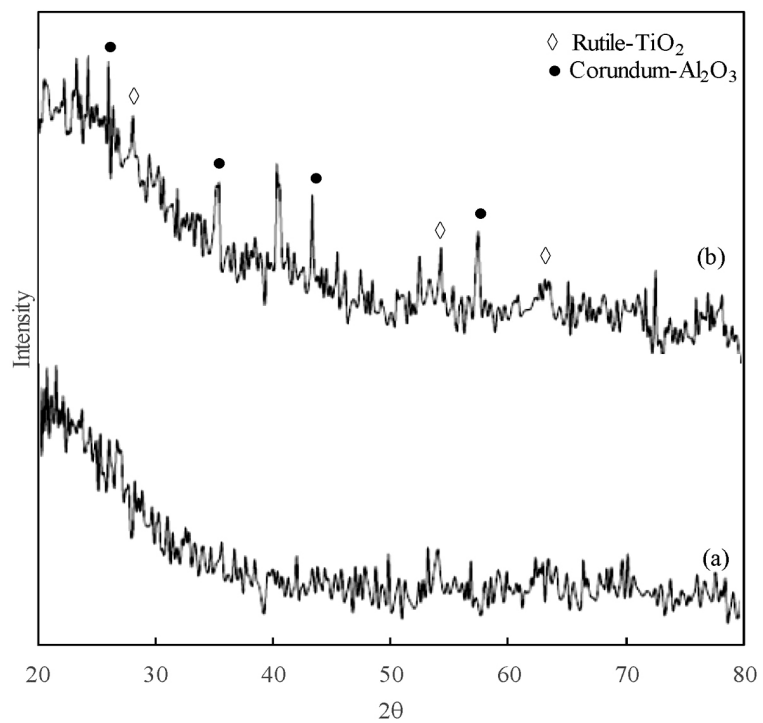

Figure 4: XRD patterns of MAO-coated Ti6Al4V with and without a nano-additive: a) MAO-Ti, b) MAO (nano)-Ti electrolyte solution. Furthermore, the Al element was found in small parts that were not well coated and came from the substrate. Figure 3 represents the EDS map analysis of the MAO coating with an addition of nano$\mathrm{Al}_{2} \mathrm{O}_{3}$. It can be seen that the prepared coating mainly consists of $\mathrm{Ti}, \mathrm{O}, \mathrm{Si}$ and $\mathrm{Na}$, which came from the substrate and electrolytic solution. From Figure 3, it can be seen that the contents of all the elements increased, the rates of $\mathrm{O}$ and $\mathrm{Al}$ changed a lot, and $\mathrm{Al}$ increased with the nano- $\mathrm{Al}_{2} \mathrm{O}_{3}$ additive. It might be inferred that the $\mathrm{Al}_{2} \mathrm{O}_{3}$ particles were mixed into the ceramic coating, with some regions partly rich in the $\mathrm{Al}_{2} \mathrm{O}_{3}$ particles. We thought that more and more dispersed nanoparticles entered the pores, increasing the nano-additive concentrations, so the coating surface became denser and smoother.

XRD patterns of MAO coatings with and without a nano-additive are shown in Figure 4. For the coating prepared in the silicate solution without nano-additives, it can be seen that the prepared ceramic coatings consist of $\mathrm{TiO}_{2}$ and the amorphous phase. The coatings prepared in the silicate solution with the $\mathrm{Al}_{2} \mathrm{O}_{3}$ nano-additive are similar; however, the peak intensity of $\mathrm{TiO}_{2}$ increased and $\mathrm{Al}_{2} \mathrm{O}_{3}$ is observed, which indicates that nanoparticles entered the prepared ceramic coatings. As mentioned in the literature, the samples with the electrolyte containing a nano- $\mathrm{Al}_{2} \mathrm{O}_{3}$ additive exhibit high voltage. This phenomenon indicates that the $\mathrm{Al}_{2} \mathrm{O}_{3}$ nano-additive has a significant influence on the voltage and thus the formation of a MAO coating. ${ }^{9,10}$

The average Vickers microhardness of the uncoated alloy was $401 \pm 10 \mathrm{HV}_{0,1}, 980 \pm 10 \mathrm{HV}_{0,1}$ and $1150 \pm 10$ $\mathrm{HV}_{0,1}$ for the MAO-Ti and MAO (nano)-Ti-coated alloys, respectively. Thus, the MAO process increased the hardness of the alloy surface significantly. This surface hardness is 2-3 times higher when compared with the uncoated sample. 


\section{CONCLUSIONS}

Ceramic coatings were generated on Ti6Al4V substrates in a silicate electrolyte with and without an $\mathrm{Al}_{2} \mathrm{O}_{3}$ nano-additive using the MAO technique. The coated layers without a nano-additive generally consisted of rutile $\left(\mathrm{TiO}_{2}\right)$. An $\mathrm{Al}_{2} \mathrm{O}_{3}$ nano-additive was successfully incorporated into the $\mathrm{TiO}_{2}$ layer, which was confirmed with XRD and EDS analyses. The added $\mathrm{Al}_{2} \mathrm{O}_{3}$ nanoparticles become incorporated into the coatings, increasing the density of the coating microstructures and the hardness. The surface hardness of the coatings was increased to $1150 \pm 10 \mathrm{HV}_{0,1}$ with the $\mathrm{MAO}$ (nano)-Ti. The surface hardness increased 2-3 times when compared with the uncoated sample.

\section{Acknowledgments}

The authors are very grateful to the Sakarya University of Turkey (Project No: 2016-01-08-018) for its support.

\section{REFERENCES}

${ }^{1}$ S. Liu, B. Li, C. Liang, H. Wang, Z. Qiao, Formation mechanism and adhesive strength of a hydroxyapatite/TiO2 composite coating on a titanium surface prepared by micro-arc oxidation, Applied Surface Science, 362 (2016), 109-114, doi:10.1016/j.apsusc.2015.11.086

${ }^{2}$ B. Attard, A. Matthews, A. Leyland, G. Cassar, Enhanced surface performance of Ti-6Al-4V alloy using a novel duplex process combining PVD-Al coating and triode plasma oxidation, Surface and Coatings Technology, 257 (2014), 154-164, doi:10.1016/j.surfcoat. 2014.07.083
${ }^{3}$ Y. Cheng, X.-Q. Wu, Z. Xue, E. Matykina, P. Skeldon, G. E. Thompson, Microstructure, corrosion and wear performance of plasma electrolytic oxidation coatings formed on Ti-6Al-4V alloy in silicate-hexametaphosphate electrolyte, Surface and Coatings Technology, 217 (2013), 129-139, doi:10.1016/j.surfcoat.2012. 12.003

${ }^{4}$ N. Xiang, R. Song, J. Zhao, H. Li, C. Wang, Z. Wang, Microstructure and mechanical properties of ceramic coatings formed on 6063 aluminium alloy by micro-arc oxidation, Transactions of Nonferrous Metals of China, (2015) 25, 3323-3328, doi:10.1016/S10036326(15)63988-7

${ }^{5} \mathrm{~K}$. Korkmaz, The effect of micro-arc oxidation treatment on the microstructure and properties of open cell Ti6Al4V alloy foams, Surface and Coatings Technology, (2015) 272, 72-78, doi:10.1016/ j.surfcoat.2015.04.022

${ }^{6}$ H. Ma, D. Li, C. Liu, Z. Huang, D. He, Q. Yan, P. Liu, P. Nash, D. Shen, An investigation of (NaPO3)6 effects and mechanisms during micro-arc oxidation of AZ31 magnesium alloy, Surface and Coatings Technology, (2015) 266, 151-159, doi:10.1016/j.surfcoat.2015. 02.033

${ }^{7}$ Y. Wang, D. Wei, J. Yu, S. Di, Effects of A12O3 Nano-Additive on Performance of Micro-Arc Oxidation Coatings Formed on AZ91D $\mathrm{Mg}$ Alloy, Journal of Material Science Technology, 30 (2014) 10, 984-990, doi:10.1016/j.jmst.2014.03.006

${ }^{8}$ Y. Hua, Z. Zhang, W. Li, Microstructure and degradation properties of C-containing composite coatings on magnesium alloy wires treated with micro-arc oxidation, Surface and Coatings Technology, 291 (2016), 70-78, doi:10.1016/j.surfcoat.2016.02.018

${ }^{9}$ H. Li, R. Song, Z. Ji, Effects of nano-additive $\mathrm{TiO} 2$ on performance of micro-arc oxidation coatings formed on 6063 aluminum alloy, Transactions of Nonferrous Metals of China, 23 (2013), 406-41, doi:10.1016/S1003-6326(13)62477-2

${ }^{10}$ M. Shokouhfar, S. R. Allahkaram, Formation mechanism and surface characterization of ceramic composite coatings on pure titanium prepared by micro-arc oxidation in electrolytes containing nanoparticles, Surface and Coatings Technology, 291 (2016), 396-405, doi:10.1016/j.surfcoat.2016.03.013 